\title{
ПРИГОТУВАННЯ ФІЛЬТРАТІВ КУЛЬТУРАЛЬНОЇ РІДИНИ ГРИБА FUSARIUM SOLANI SACC. ДЛЯ ВИКОРИСТАННЯ В КЛІТИННІЙ СЕЛЕКЦІЇ БАКЛАЖАНА НА СТІЙКІСТЬ ПРОТИ ФУЗАРІОЗНОГО В'ЯНЕННЯ
}

\section{Т. В. Івченко, Г. В. Мозговська}

Інститут овочівництва і баштанництва НААН

Досліджено різні способи отримання фільтратів культуральної рідини збудника фузаріозного в'янення Fusarium solani Sacc. Встановлено, що в дослідженнях 3 клітинної селекції баклажана оптимальними є добори на селективних середовищах з 40 або 50 \% вмістом фільтратів культуральної рідини, культивованих на середовищі за прописом Річардсона

Баклажан, фільтрат культуральної рідини (ФКР), поживне середовище Чапека і Річардсона, культивування, токсичність

Баклажан відноситься до числа найбільш цінних овочевих культур завдяки високому вмісту в плодах заліза, сахарози $(2,2-4,6 \%)$, білку $(0,6-$ $1,4 \%)$, жиру $(0,1-0,4 \%)$, клітковини (1-2 \%), зольних речовин $(0,4-0,7 \%)$, води (91-94\%) [1]. Але в останні п’ять років виробництво та продуктивність цієї культури зазнає негативного впливу біотичних та абіотичних факторів, що позначається на зменшенні врожайності та якості продукції. Найбільш шкодочинним захворюванням баклажана є фузаріозне в'янення, збудник якого сапрофітний паразит Fusarium solani Sacc., призводить до загибелі рослин внаслідок закупорення провідних судин рослин гіфами гриба. У боротьбі з фузаріозним в'яненням створення стійких сортів визнано найбільш ефективною стратегією [2], так як обмеження розвитку цієї хвороби за допомогою фунгіцидів не $\epsilon$ ефективним. Крім того, деякі хімічно синтезовані фунгіциди можуть призвести до екологічного забруднення. Оскільки діяльність людини призвела до прискорення мікроеволюції патогенів, тому для селекції нових сортів активно залучати нові сучасні методи, в тому числі клітинну селекцію in vitro. Доступність достатньої генетичної мінливості і ефективні процедури добору - дві головні можливості, які забезпечує ця технологія. Велике значення для оцінки і добору стійких форм має пошук оптимального селективного фактору in vitro, пов'язаного з механізмом патогенезу in vivo. Він має велике значення для оцінки і добору. В науковій літературі представлено результати селекції стійких до фузаріозного

(C) Т. В. Івченко, Г. В. Мозговська. 2013.

ISSN 0582-5075. Селекція і насінництво. 2013. Випуск 103. 
в'янення генотипів з використанням ФКР збудників хвороб [3]. Перспективність даного напрямку досліджень підтверджено вченими з Індії, створенням генотипів баклажана 3 підвищеною стійкістю проти фузаріозного в'янення [4], стійких сортів баклажана проти фомопсису [5] та вертицильозного в'янення [6].

Для успішного виконання роботи з клітинної селекції необхідно, насамперед, підготувати ФКР збудника та підібрати таку його концентрацію, яка б дозволяла виявляти чітку різницю у стійкості до селективного агенту різних ліній, але не призводила до летального впливу на клітини. Саме тому метою досліджень було розробити методику приготування селективних середовищ з ФКР патогенних штамів Fusarium solani та визначити їх оптимальні концентрації у середовищах для проведення доборів стійких калюсних клонів баклажана.

Методика проведення досліджень. Досліди виконували за загальноприйнятими біотехнологічними методами при використанні стандартного обладнання [7]. У дослідженнях використовували різний за рівнем толерантності до фузаріозного в'янення селекційний матеріал баклажана: районовані сорти Прем'єр і Алмаз, гібриди покоління $\mathrm{F}_{4} 3$ селекційного розсаднику ІОБ НААН та міжвидовий гібрид $\mathrm{F}_{4}-\uparrow S$. melongena $\mathrm{L}$. / ${ }^{7} S$. aethiopicum gr. Gilo. Чисті культури $F$. solani отримували за стандартною методикою Білай [8]. Ідентифікацію збудників фузаріозного в'янення проводили за морфологокультуральними ознаками (колір і характер росту міцелію, колір строми) та при мікроскопічному дослідженні з урахуванням морфологічних особливостей та розмірів макроконідій. 3 колекції ізолятів патогенів виділяли моноспорові культури, які додатково розмножували 3 пасажі у чашках Петрі. Для приготування ФКР патогену у чашки Петрі з популяцією гриба додавали по 5 мл автоклавованої води, після чого за допомогою шпателя з поверхні середовища змивали конідії. Отриману суспензію в стерильних умовах фільтрували і проводили підрахунок спор під мікроскопом у камері Горяєва. Визначивши необхідну концентрацію конідій $\left(2 \cdot 10^{7} /\right.$ мл), по 1 мл суспензії додавали до 200 мл рідких середовищ приготованих за прописом Чапека [8] та Річардсона [9], які інкубували 21 день у термостаті за температури $26^{\circ} \mathrm{C}$. Контролем слугували колби зі стерильною водою. Фітотоксичність одержаних на різних середовищах фільтратів проводили за рекомендаціями К. М. Черненко [10] на семидобових проростках різних за ступенем стійкості сортів баклажана: Прем'єр - сприйнятливий, Алмаз - стійкий. Повторність досліду чотириразова, у кожній повторності по 50 насінин. Для оцінки токсичності фільтратів проростки 10 діб інкубували у чашках Петрі з додаванням одержаного на середовищах Чапека та Річардсона ФКР у концентраціях 25, 50 \% та 100 \% і на середовищах Чапека та Річардсона без патогену. В якості контролю слугувала дистильована вода. Культивування матеріалу проводили за температур $22-24{ }^{0} \mathrm{C}$ та денному освітленні. Щоденно відмічали життєздатність проростків, довжину кореня та ознаки прояву хвороби. 
Оцінку впливу ФКР на калюсогенез проводили на чотирьох генотипах баклажана з різною польовою стійкістю до хвороби. В якості донорського матеріалу використовували сім'ядолі семиденних проростків, які висаджували на розроблене індукційне середовище Мурасиге-Скуга [11], модифіковане регуляторами росту (2 мл/л ІОцК і 4 мл/л БАП ) без додавання ФКР (контроль) та $з$ концентрацією селективного агенту $20 \%, 40$ \%, 60 \% від об'єму середовища. Культивування калюсів відбувалось за температури 22 - $24{ }^{\circ} \mathrm{C}$ та 16-годинного фотоперіоду за освітлення 2 тис. люкс. Вплив різних концентрацій ФКР визначали за морфометричними показниками розвитку калюсної тканини на селективних середовищах у відсотках до контролю та за показниками життєздатності експлантатів після чотирьох тижнів культивування.

Результати досліджень $i$ їх обговорення. У результаті досліджень встановлено, що на 10 день після закладання досліду спостерігалась загибель значного відсотку проростків баклажана у варіантах 3 додаванням ФКР, тоді як на контролі (вода дистильована) та на варіантах 2 i 6 (середовища Чапека і Річардсона без ФКР) всі проростки були життєздатними (табл. 1). При інкубуванні насіння баклажану досліджуваних генотипів у нерозведеному фільтраті культуральної рідини проростки набували антоціанового забарвлення, корінці буріли (вар. 5 і 9) і на дев'ятий день дослідження загнивали і відмирали.

На варіантах з меншими концентраціями ФКР проростки були гетерогенними у чутливості до фільтрату. Найвищий відсоток життєздатних проростків спостерігався за використання ФКР, одержаному на середовищі Чапека, від $37 \%$ до 52 \% за культивування при додаванні 20 \% ФКР та 18,4 - 34,0 \% при 50 \% ФКР. У варіантах, де використовували фільтрати, одержані на середовищі Річардсона, відсоток життєздатних проростків був меншим - від $29 \%$ до 43 \% при додаванні 20 \% ФКР та 14,0 - 22,0 при 50 \% ФКР. Вплив фільтратів культуральної рідини гриба проявився також у пригніченні росту корінців у життєздатних проростків. На варіантах, де насіння пророщували на середовищах Чапека і Річардсона без фітопатогену довжина коренів проростків на 10 день становила $3,4 \pm 0,3-3,6 \pm 0,3$ см і значно перевищувала аналогічний показник на контролі $2,2 \pm 0,2-2,4 \pm 0,2$ см, що пояснюється використанням проростками для розвитку комплексу мінеральних речовин та вуглеводів, які входили до складу середовищ. Проростки використаних у досліді генотипів баклажана проявили також різну чутливість до ФКР. Для сприйнятливого сорту Прем'єр дія ФКР на середовищі за прописом Річардсона (варіанти 7-8) була більш токсичною, ніж для стійкого сорту Алмаз, що проявилосьяк у низькій життєздатності насінин (від $14 \%$ до 29 \%), так і у відставанні у розвитку корінців (1,1 $\pm 0,1-1,4 \pm 0,1$ см). Рослини сорту Алмаз на середовищі Річадсона 3 ФКР мали вищі показники як за життєздатністю (від 22,0 \% до 43,0%),

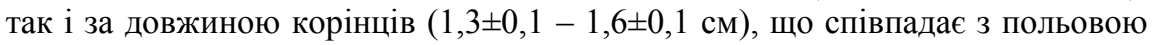
оцінкою використаних генотипів до фузаріозного в'янення. 
Таблиця 1

Вплив різних концентрацій ФКР, приготованих за прописами Чапека і Річарсона, на життєздатність і довжину корінців проростків баклажана через 10 діб культивування

\begin{tabular}{|c|c|c|c|c|c|}
\hline \multirow{3}{*}{$\begin{array}{l}\text { № } \\
\text { вар. }\end{array}$} & \multirow{3}{*}{$\begin{array}{c}\text { Середовище для проро- } \\
\text { стання насіння }\end{array}$} & \multicolumn{4}{|c|}{ Генотипи } \\
\hline & & \multicolumn{2}{|c|}{ Прем’єр } & \multicolumn{2}{|c|}{ Алмаз } \\
\hline & & $\begin{array}{l}\text { Життєздатних } \\
\text { проростків, \% }\end{array}$ & $\begin{array}{c}\text { Довжина корін- } \\
\text { ців проростків, } \\
\text { см }\end{array}$ & $\begin{array}{l}\text { Життєздатних } \\
\text { проростків, \% }\end{array}$ & $\begin{array}{c}\text { Довжина корін- } \\
\text { ців проростків, } \\
\text { см }\end{array}$ \\
\hline 1 & $\begin{array}{l}\text { Вода дистильована } \\
\text { (контроль ) }\end{array}$ & 100,0 & $2,2 \pm 0,1$ & 100,0 & $2,4 \pm 0,2$ \\
\hline 2 & Чапека без ФКР & 100,0 & $3,4 \pm 0,3$ & 100,0 & $3,6 \pm 0,3$ \\
\hline 3 & Чапека 325 \% ФКР & 37,0 & $1,6 \pm 0,2$ & 52,0 & $1,9 \pm 0,2$ \\
\hline 4 & Чапека 350 \% ФКР & 18,4 & $1,3 \pm 0,1$ & 34,0 & $1,6 \pm 0,1$ \\
\hline 4 & Чапека з $100 \%$ ФКР & 0 & 0 & 0 & 0 \\
\hline 5 & Річарсона без ФКР & 100,0 & $3,5 \pm 0,3$ & 100,0 & $3,7 \pm 0,3$ \\
\hline 6 & Річарсона з $25 \%$ ФКР & 29,0 & $1,4 \pm 0,1$ & 43,0 & $1,6 \pm 0,1$ \\
\hline 7 & Річарсона $350 \%$ ФКР & 14,0 & $1,1 \pm 0,1$ & 22,0 & $1,3 \pm 0,1$ \\
\hline 8 & Річарсона з $100 \%$ ФКР & 0 & 0 & 0 & 0 \\
\hline
\end{tabular}


При пророщуванні насіння сорту Алмаз з додаванням ФКР за прописом Чапека відсоток життєздатності був більше на 11 \%, ніж на середовищі Річарсона, що свідчить про більшу фітотоксичність фільтратів використаних у варіантах 7 та 9 над фільтратами у варіантах 3 i 5 за прописом Чапека, для обох використаних в досліді генотипів.

На другому етапі досліджень проведено додаткову оцінку ефективності використання фільтратів одержаних на середовищах Чапека і Річарсона для добору в культурі in vitro за двохступінчастою схемою стійких проти ФКР F. solani сомаклонів баклажана.

Як показав експеримент (табл. 2), на контрольному варіанті досліду при використанні базового середовища МС, модифікованого регуляторами росту 2 мл/л ІОцК і 4 мл/л БАП, у всіх генотипів відмічалась індукція калюсогенезу з показниками ліміту мінливості ознаки від $862,3 \pm 3,15$ до $1283,1 \pm 2,33 \mathrm{mм}^{3}$, що підтвердило ефективність розробленої нами регенераційної системи для проведення клітинної селекції баклажана. На середовищах 3 додаванням ФКР фітотоксична дія фільтратів проявилась у зменшенні об'єму індукованої калюсної тканини у всіх досліджуваних генотипів та зниженні життєздатності експлантатів.

Отримані результати свідчать про гетерогенність сприйнятливості експлантатів використаних в досліді генотипів до дії ФКР. Так, реакція в умовах in vitro стійкого проти фузаріозного в'янення генотипу - міжвидового гібрида б. к. 13 (S. melongena L / S. aethiopicum gr. Gilo.) на присутність у середовищі ФКР патогену відповідала результатам польової оцінки - калюси цього генотипу були слабо сприйнятливими до дії низьких (20 \%) і високих концентрацій (40\% ФКР) у середовищі. За отриманими показниками життєздатності генотип б. к. 13 перевищував генотип західно-азіатського походження б. к. 40. На середовищах з 20 і 40 \% ФКР його експлантати були слабо сприйнятливими до дії селективного фактору. При культивуванні на селективному середовищі з 40 \% ФКР цей генотип мав найбільші показники калюсогенезу: 853,2 $\pm 5,16$ мм $^{3}$ на середовищі з ФКР за прописом Річардсона та $1100,3 \pm 5,22$ мм $^{3}$ на середовищі з ФКР за прописом Чапека. Експлантати генотипу б. к. 29 проявили себе як толерантні до дії ФКР. На селективних середовищах у цього генотипу спостерігалось значно більше зниження життєздатності: від 55,8 \% до 61,3 \% на середовищі з 20 \% ФКР та від 34,8 - 54, 5 \% на середовищі з $40 \%$ ФКР, та невисокі темпи наростання біомаси калюсних клітин. Найбільшу чутливість до дії ФКР показав себе генотип східно - азійського походження б. к. 2, для якого культивування на всіх варіантах з ФКР виявились летальними. Висока концентрація фільтрату культуральної рідини у селективних середовищах - 60 \%, виявилась летальною для всіх генотипів.

Сім'ядолі генотипів б. к. 29 та б. к. 40 пожовкли вже на другому тижні культивування, а сім'ядолі генотипів б. к. 13 та б. к. 40 на четвертому тижні, після чого вони некротизувались і загинули. 
Таблиця 2

Вплив різних концентрацій ФКР гриба Fusarium solani, одержаних за прописами Чапека і Річарсона на індукцію калюсогенезу з сім'ядольних експлантатів різних генотипів баклажана

\begin{tabular}{|c|c|c|c|c|c|c|c|c|}
\hline \multirow[b]{2}{*}{$\begin{array}{l}\text { Каталог } \\
\text { генотипу }\end{array}$} & \multirow[b]{2}{*}{$\begin{array}{c}\text { Походження } \\
\text { генотипу }\end{array}$} & \multirow[b]{2}{*}{ Варіанти } & \multicolumn{3}{|c|}{ Середовище Чапека } & \multicolumn{3}{|c|}{ Середовище Річардсона } \\
\hline & & & $\begin{array}{c}\text { життє- } \\
\text { здатність, } \\
\% \\
\end{array}$ & $\begin{array}{c}\text { середній } \\
\text { діаметр } \\
\text { калюсу, мм } \\
\end{array}$ & $\begin{array}{c}\text { у \% до } \\
\text { контролю }\end{array}$ & $\begin{array}{c}\text { життє- } \\
\text { здатність, } \\
\% \\
\end{array}$ & $\begin{array}{c}\text { середній } \\
\text { діаметр } \\
\text { калюсу, мм } \\
\end{array}$ & $\begin{array}{c}\text { у \% до } \\
\text { контролю }\end{array}$ \\
\hline \multirow{4}{*}{ Б. к. 13} & \multirow{4}{*}{$\begin{array}{c}\text { міжвидовий } \\
\text { гібрид }\end{array}$} & $\begin{array}{c}\text { Без ФКР } \\
\text { (контроль) }\end{array}$ & 100 & $1283,1 \pm 2,33$ & 100 & 100 & $1281,6 \pm 2,35$ & 100 \\
\hline & & $20 \%$ ФКР & 92,1 & $1225,4 \pm 6,11$ & 95,5 & 48,4 & $856,3 \pm 3,20$ & 66,8 \\
\hline & & $40 \%$ ФКР & 64,2 & $810,5 \pm 5,14$ & 63,2 & 34,3 & $764,8 \pm 4,82$ & 59,7 \\
\hline & & $60 \%$ ФКР & 0 & 0 & 0 & 0 & 0 & 0 \\
\hline \multirow{4}{*}{ Б. к. 40} & \multirow{4}{*}{$\begin{array}{l}\text { західно- } \\
\text { азіатський }\end{array}$} & $\begin{array}{c}\text { Без ФКР } \\
\text { (контроль) }\end{array}$ & 100 & $1251,4 \pm 5,23$ & 100 & 100 & $1274,1 \pm 6,56$ & 100 \\
\hline & & $20 \%$ ФКР & 94,3 & $1210,2 \pm 5,31$ & 96,7 & 76,8 & $1101,7 \pm 7,25$ & 86,5 \\
\hline & & $40 \%$ ФКР & 76,1 & $1100,3 \pm 5,22$ & 87,9 & 32,3 & $853 \pm 5,16$ & 66,9 \\
\hline & & $60 \%$ ФКР & 0 & 0 & 0 & 0 & 0 & 0 \\
\hline \multirow{4}{*}{ Б. к. 29} & \multirow{4}{*}{$\begin{array}{c}\text { східно- } \\
\text { азіатський }\end{array}$} & $\begin{array}{c}\text { Без ФКР } \\
\text { (контроль) }\end{array}$ & 100 & $940,2 \pm 5,23$ & 100 & 100 & $939,1 \pm 5,21$ & 100 \\
\hline & & $20 \%$ ФКР & 84,1 & $576,2 \pm 6,11$ & 61,3 & 54,2 & $523,6 \pm 6,23$ & 55,8 \\
\hline & & $40 \%$ ФКР & 63,5 & $512,3 \pm 5,15$ & 54,5 & 25,4 & $327,25 \pm 8,44$ & 34,8 \\
\hline & & $60 \%$ ФКР & 0 & 0 & 0 & 0 & 0 & 0 \\
\hline \multirow{4}{*}{ Б. к. 2} & \multirow{4}{*}{$\begin{array}{c}\text { східно- } \\
\text { азіатський }\end{array}$} & $\begin{array}{c}\text { Без ФКР } \\
\text { (контроль) }\end{array}$ & 100 & $862,3 \pm 3,15$ & 100 & 100 & $861,2 \pm 3,16$ & 100 \\
\hline & & $20 \%$ ФКР & 65,2 & $729,6 \pm 4,56$ & 84,6 & 30,1 & $632,50 \pm 4,12$ & 73,4 \\
\hline & & $40 \%$ ФКР & 56,1 & $343,3 \pm 4,13$ & 39,8 & 21,3 & $249,0 \pm 4,15$ & 28,9 \\
\hline & & $60 \%$ ФКР & 0 & 0 & 0 & 0 & 0 & 0 \\
\hline
\end{tabular}


Такі результати дозволили зробити висновок, що найбільш оптимальним для використання в дослідженнях 3 клітинної селекції стійких до ФКР пробіркових рослин баклажана є добори на селективних середовищах 3 $40 \%$ або 50 \% вмістом підготовлених за прописом Річадсона ФКР.

Більш жорсткий скринінг експлантатів всіх досліджених у досліді генотипів відбувався при використанні ФКР, виготовленого за прописом Річардсона, у порівнянні з ФКР за прописом Чапека. Відмінності спостерігались як за параметрами життєздатності, так і за розвитком калюсогенезу. Середовище Річадсона відрізнялось від середовища Чапека збільшеним у ньому в п’ять разів вмістом $\mathrm{N}, \mathrm{P}, \mathrm{K}, \mathrm{Mg}$, заміненою сульфатної форми заліза на хлоридну, збільшеної у два рази концентрацією сахарози і амінокислот. За рахунок модифікації умов культивування патогенного гриба $F$. solani у середовищі Річадсона створювалися умови для покращення умов культивування конідіальної суспензії у культуральному середовищі, підвищенню синтезу мікроміцетом мікотоксинів, за рахунок чого було отримано ФКР із високими фітотоксичними якостями.

Висновки: Найбільш оптимальним для використання в дослідженнях з клітинної селекції є добори на селективних середовищах з $40 \%$ або 50 \% вмістом ФКР, культивованому на середовищі за прописом Річардсона.

\section{Список використаних джерел}

1. Magioli C. Eggplant (Solanum melongena L.): tissue culture, genetic transformation and use as an alternative model plant Acta bot. Bras / C. Magioli, E. Mansur. - 2005. - P. 19(1): 139-148.

2. Исходный материал для селекции озимой мягкой пшеницы на групповую устойчивость к фитопатогенам / Л. Т. Бабаянц, О. В. Бабаянц, А. А. Васильев [та ін.] // Зб. наукових праць СГІ-НЦНС. - Одеса, 2007. - Вип. 9 (49). - C. 224-237.

3. Jayashankar $S$. In vitro selection of Vitis vinifera Chardonnay with Elsinoe ampelina culture filtrate is accompanied by fungal resistance and enhanced secretion of chitinase / S. Jayashankar, Z. Gray. -2000. - P. 200-208.

4. Chelliah $S$. Resistance in bhindi, brinjal and tomato to major insect and mite pests Proceedings of the National Seminar on Breeding Crop Plants for Resistance to Pests and Diseases / S. Chelliah, K. Srinivasan. - Tamil Nadu, India, 1983. - P. 47.

5. Kalda T. S. Resistance to Phomopsis blight in eggplant / T. S. Kalda, K. Swarup, B. Chowdhury. - Veg. Sci., 1977. - P. 90-101.

6. Melo I. S. Resistance reaction of aubergine progenies to Verticillium alboatrum Reinkes Berth / I. S. Melo, C. D. Costa. - Summa, 1985. - P. 180-185. 
7. Методика досліджень в культурі ізольованих тканин овочевих рослин / [В. П. Мірошніченко, О. Ф. Сергієнко, Т. В. Івченко та ін.]. - Мерефа: ІОБ УААН, 2004. $-25 \mathrm{c}$.

8. Билай В. И. Фузарии / В. И. Билай. - К. : Наукова думка, 1977. - 443 с.

9. Richard P. Richard's solution / P. Richard // Plant Pathologists Pocketbook, 1968.

10. Черненко $К$. М. Діагностика стійкості моркви проти чорної гнилі експрес-методом за насінням / К. М. Черненко // Зб. наукових праць УААН відділення рослинництва і переробки продукції. - Аграрна наука, 1999. C. 209-210.

11. Murashige T. A revised medium for rapid growth and bioassay with tobacco tissue cultures / T. Murashige, F. Skoog. - Plant Physiology, 1962. P. 473-497. 